Rev. Dariusz Lipiec

\title{
The implications of the teaching of Pope Francis for youth ministry during World Youth Day in Krakow
}

The article has raised the issue of the implications of papal teaching during World Youth Day in Krakow in 2016 for the youth ministry, and especially for the youth ministry in Poland. At the beginning the condition of today's youth was shown in terms of the teaching of Pope Francis. Then, there were defined the main objectives of the pastoral care of young people based on the analysis of the Pope's teaching. They are: assistance in meeting God, help in the discovery of the own vocation and help to make the apostolate proper to all the baptized. In the framework of these objectives there have been identified some specific, detailed tasks for clergy working with young people and their lay volunteers.

Key words: Francis, World Youth Day, youth ministry.

The origins of the World Youth Day dates back to the Jubilee Year of the Redemption, celebrated in the Church from March 25, 1983 to April 22, 1984. On Palm Sunday 1984 a large crowd of young people came to Rome at the invitation of Pope St. John Paul II. At the end of the meeting, on St. Peter's Square, the Pope entrusted the cross to young people and expressed the wish to carry it through life and give it to the world. The following year, 1985, has been declared the United Nations International Year of Youth. The Catholic Church joined in its celebration. On this occasion, the Pope published a number of documents relating to the youth issues among which The Apostolic Letter to the Youth „Parati semper” is one of the most important. The central 
ceremony took place in Rome on 30-31 March 1985. On Saturday, young people gathered in front of the Basilica of St. John Lateran, and on Palm Sunday at St. Peter's Square for common prayer gathered 300 thousand young people from 70 countries of the world. Palm Sunday has been announced the day of young people by St. Pope John Paul II. It was assumed at the time that World Youth Day would be held annually and alternately: one year in the dioceses, the next in a designated place by the Pope. The first World Youth Day took place in the dioceses, and the second one were in Buenos Aires.

The intention of St. John Paul II about World Youth Day are to deepen ties of young people with God and the Church. They give the possibility of mutual enrichment of the faith and love and the experience of universality and youth of the Church. They also serve to build fraternal relations between young people of different races, cultures and traditions, and overcoming prejudices and fears. Priests are given the opportunity to reflect on the issues of young people who should find their place in the Church. According to St. John Paul II, the youth is the future of the Church and the pastoral care should be the priority in the implementation of the mission of the ecclesial community ${ }^{1}$.

XXXI World Youth Day held in Krakow on 27-31 July 2016 under the leadership of Pope Francis. He maintains the pastoral initiative taken by the Polish Pope and continued by Benedict XVI. He retains the idea of a formula developed by the predecessors, giving World Youth Day a current content. The message of Francis addressed to young people is in line with the whole of his teaching. There is the reflection of the main ideas of his pontificate. It can be read also implications for the youth ministry, which like the entire pastoral ministry of the Church, is to be missionary and lead the young man to meet and bond with God and the discovery of his vocation and mission. According to Francis, the central idea of the youth ministry that should be used by the clergy is the proximity ${ }^{2}$. The proximity can be understood as a pastoral principle and the form of staying with the young people by the priests. The proximity principle is anchored in the condition of the contemporary youth, which shapes and forms pastoral work.

$1 \quad$ Cf.Bp A.Długosz, Młodzieży duszpasterstwo, [in:] Leksykon teologii pastoralnej, R. Kamiński, W. Przygoda, M. Fiałkowski eds., Lublin 2006 p. 513.

2 Francis, The preaching during the meeting with polish bishops. Gospel of Intimacy (Kraków - Wawel 27.07.2016). OsRomPol 47:2016 no. 7-8 p. 7. 


\section{The contemporary youth as a recipient of pastoral care}

From the teaching of Francis during World Youth Day in Krakow emerges complicated and ambiguous image of the contemporary youth. This image correlates with the image of the world in which young people live. They live in the world that determines their existence and shapes them ${ }^{3}$. The Pope notes primarily natural dynamism and enthusiasm of young people ${ }^{4}$. These features allow them to look with hope to the future and make plans and dreams of adulthood, when they can realize themselves, raise a family, work and play various social roles. This hope allows young people to come out from the circle of their own affairs and asking for others. Young people, as is noted by Francis, want to change the world by making it more just and human.

However, not everywhere young people have the right conditions to implement their plans. The obstacles are often complex - of cultural, economic and political background. Many young people live in countries stricken by armed conflict. In some regions of the world there are civil wars, in others there are conflicts between neighbors. These conflicts are usually complex. They break out because of ethnic, religious, racial basis ${ }^{5}$. Mostly, however, they have the economic base, as notes Francis, because one group of people, especially the rich use the poor. Armed conflicts pose a threat primarily to the existence of people, including young people and children. Consuming countries and societies they are becoming a source of poverty and contribute to a significant reduction of the development prospects of societies and individuals. This is particularly acute in the case of young people who cannot see the development prospects and lose hope, and many of them are subjected to currents of hatred and violence. Francis also recognizes the diversity of spiritual condition of the contemporary youth. He talked with joy about young people who want to change the world and get involved for the good of others. They make an effort because of the love of God and neighbor through prayer, sacrifice of suffering and work ${ }^{6}$. There are also those called " "early retirement"

$3 \quad$ H. Tomasik. Wychowanie młodych do wiary, [in:] Głosić Ewangelię nadziei. Program duszpasterski na rok 2004/2005, P. Kurzela, A. Liskowacka eds., Katowice, p. 106-115.

4 Francis, Speech Poland wants to be a forever young face of mercy (Kraków Błonia 28.07.2016), OsRomPol 47:2016 no. 7-8. p. 15.

$5 \quad$ Ibidem, Speech Nothing justifies the shed of brotherly blood (Brzegi 30.07.2016), OsRomPol 47:2016 no. 7-8, p. 25.

$6 \quad$ Ibidem, Speech Two conditions- memory and courage (Kraków - Tauron Arena 31.07.2016), OsRomPol 47:2016 no. 7-8. p. 31. 
by Francis. These are young people, , have "thrown in the towel” before the game has even begun, who are defeated even before they begin to play, who walk around glumly as if life has no meaning. Deep down, young people like this are bored... and boring!". ${ }^{7}$ The challenge for priests are also young people who , waste their lives looking for thrills or a feeling of being alive by taking dark paths and in the end having to pay for it... and pay dearly"s.

Next to them there are the young people called by Francis as ,"sluggish, muddle-headed, dazed" who confuse „luck with the couch." These young people „, need the couch for their happiness. The couch where [...] they can be indulgent, calm and quite safe. The couches as those that are now modern [...] and guarantee hours of peace [...]. The couch for all kinds of pain and fear. The couch inducing [...] to remain confined at home, without effort and worrying. Couch luck is probably a silent paralysis, which can [...] the most destroy the youth"9.

\section{Assistance in meeting God}

Many problems of the modern youth have the source in a distance from God. A large group of young people have not met Him in their life and have not established a personal relationship with Him. As the primary objective of the youth ministry appears thus leading young people to a personal encounter with God, and then to deepen this relationship. This goal stems from the proximity principle, which the Church should - according to the teaching of Francis - direct in his ministry. The proximity of the priests and consorting young people cannot be limited only to staying with them. The proximity in this case means a more common way of priests and the youth. This road is heading for God. It is about an encounter with God in eternity, but especially in the temporality. It is this aspect of the consorting young people highlights the Pope. Earthly life is understood by him as a gift of God, which is of great value. The gift that cannot be wasted, but should be developed for the other, for each other and for God.

Francis showed the young people God as a merciful Father, who is close to a man. This proximity means deep involvement of God in human life. Involvement of God is of existential and emotional character. The relationship between God and a man is characterized by tenderness and warmth. God in fact depends on the man and his happiness.

\footnotetext{
$7 \quad$ Ibidem, Speech Poland wants to be a forever young face of mercy, p. 16.

8 Ibidem.

$9 \quad$ Ibidem, Speech Nothing justifies the shed of brotherly blood, p. 26.
} 
Therefore, God takes the initiative and goes to meet him, opening for his person and his welfare ${ }^{10}$. Many people today, especially young people, do not reciprocate God's merciful love. According to Francis, the main reason for this is ignorance of God. It is caused primarily by the fact that no one preached young people the truth about God and did not explain or did it so incompletely. For this reason, the proximity of priests means introducing into the closeness of God, understood as a guidance to Him, getting to know Him and existential adherence to Him.

Spiritual guidance of young people on the way to the Father is Pastoral also to take into account their situation in life, especially all kinds of restrictions. Many young people are wounded, experience a situation of rejection, humiliation or marginalization. It is hard for them to discover the presence of God in a world characterized by a lack of justice, stability, and among people presenting negative moral attitudes ${ }^{11}$. As the task of the Church and its priests appears in this regard the need to show the closeness of God through the testimony of the life and selfless service, reaching up to the dedication and sacrifice ${ }^{12}$.

The purpose of the youth ministry is also helping in the meeting Christ. According to Francis, the encounter with Christ means a complete unification with Him. This is due to His invitation: He unites himself with each man, especially with a weak and needy man. A man, also young, experiencing his own weakness, should turn to Christ and unite with Him. The task of the disciple of Christ is to give yourself to Him, total trust and entrusting Him the life. This disciple attitude stems from love which he gives to his Savior who offered himself for a man. It was a sacrifice of suffering ${ }^{13}$. That is why Jesus is a gift for a man.

Entrusting ourselves to Christ results in the transformation of the young man's life. The source of this transformation is in Jesus, who enters into a human life. He acts inside the man making this change deep and profound. As Francis teaches: „Jesus can give you true passion for life. Jesus can inspire us not to settle for less, but to give the very best of ourselves" ${ }^{14}$. The most important result of meeting

$10 \quad$ Ibidem, Speech Where is God? (Kraków - Błonia 29.07.2016), OsRomPol 47:2016 no. 7-8, p. 20-21.

11 Cf. K. Święs, Obraz wspótczesnej młodzieży w Polsce, „Warszawskie Studia Pastoralne" 9:2014, p. 52-54.

12 Ibidem, Homily We write down cards of the Gospel of love by our life (Kraków - Sanktuarium Jana Pawła II 30.07.2016), OsRomPol 47:2016 no. 7-8. p. 24.

13 Ibidem, Speech Where is God?, p. 21.

14 Ibidem, Speech Poland wants to be a forever young face of mercy, p. 16. 
Jesus is love. Through the union with Christ, His love passes into a man. A man acquires the love of God, which means that the love that he himself has is not human and natural but it is supernatural love. Love is a gift of God to a man, but man cannot always love, that is to endow others with love. Therefore, meeting Christ makes a young man acquire the Teacher who teaches to love as God and other people. Christ is so the Giver and the Teacher of love for the youth. This teaching is a complicated process. The young man should first take care about the development of love, and then to love God and people. In this process, it is necessary the presence of other people, who are masters of the spiritual life. Their presence is to help reach Jesus, open up to him, and then there is the process of systematic growth in love. The presence and support of the priests is nowadays very necessary because young people not only often fall because of human weakness, but also often fall into discouragement after unsuccessful trials of the life with Christ. Francis in his teaching claims that proximity of priests in relation to young people is a long process that requires patience, because the weakness of the young generation is manifested in many surprising situations ${ }^{15}$.

\section{Aid in the discovery of vocation}

The union with God makes the young person acquires another self-image. He gains a new identity. He discovers that he is a child of God and he looks through God's eyes at himself, at the world in which he lives and at the people around. He begins to perceive himself as the recipient of the merciful love of God, and therefore as being important and expected in his eyes as His son or daughter. At the same time, a young man discovers the spiritual kinship with Christ, the Son of God. He is perceived as a Savior, and also as a Teacher and a Guide through the life. Binding oneself and one's own existence with God tells the young man to look in a different optics to the future and ask questions about life. These are the questions about the meaning of human life, the importance of work and suffering, and many others related to the current situation. Among these questions there are also questions about the self, existence and the purpose of life.

The teaching of Francis during World Youth Day in Krakow points that help for young people in discovering their vocation is a big challenge for the youth ministry. The complicated situation in the contemporary world, and especially the socio-cultural currents favor

$15 \quad$ Ibidem. 
their loss, and consequently the resignation of putting fundamental existential questions. The result of this state of affairs is passivity in making higher goals and limiting to satisfy existential needs. Spiritual apathy and lack of higher goals of young people, in turn, promotes the adoption of consumer attitudes and consequently build a consumer society. Young people are threatened with closure in the circle of their own affairs and treating other people as tools to satisfy their selfish purposes.

The task of priests is to encourage young people to think and make them search greater values than the consumer goods ${ }^{16}$. This means bringing into their lives some kind of existential anxiety. It is a difficult and unrewarding activity because laziness and comfort of many young people are the cause of the opposition and even revolt against those who bring their lives anxiety. However, it is necessary to provoke young people to abandon the formulaic ways of thinking and evaluating. It is about directing their attention toward higher values, and especially to love, which is the principle of social life. The result of this stimulation is to develop by young people the confidence that they do not live only for themselves but also for others ${ }^{17}$. Only on the basis of altruism you can ask questions about the vocation, and then assist in giving the answers.

During the XXXI World Youth Day Francis emphasized the discovery by the youth of the Christian vocation. To a lesser extent he drew attention to the realization of the vocation to marriage and family life, the priesthood and the consecrated. Analyzing the teaching of the Pope concerning the calling to be married it can be concluded that the essential pastoral task is concern for the deepening of ties between the spouses. This is due to several reasons. The first one is the human imperfection. In marriage reveals the imperfections of a husband and a wife, which hinder the development of their relations, so it is necessary to support them and provide spiritual direction, which helps to know oneself and the spouse. Another reason is the inadequate or not sufficient preparation. Living together verifies this state of affairs, and the lack of support from the Church means that the difficulties are not always overcome, which in turn can lead to the dissolution of

16 Cf. A. Długosz, Duszpasterstwo młodzieżowe wobec nowych wyzwań, [in:] Głosić Ewangelię nadziei. Program duszpasterski na rok 2004/2005, p. 138-139.

$17 \quad$ Francis, Speech Nothing justifies the shed of brotherly blood, p. 27. 
marriage. What is needed is support for marriage and the family by the priests for deeper maturation of the couple and their relationship ${ }^{18}$.

Francis sees consecrated and spiritual people as responsible for the Church, especially the laity. He presented the relationship between the clergy and the laity in the convention of the subject and the object of care. While the laity are portrayed as poor and needy, priests are responsible for their fate. It is all about their spiritual condition in the temporal and the eternal salvation. The Pope emphasized the duty to give oneself to the service of God and the Church, especially the laity. The motive here is pastoral charity, which has its source in God's merciful love. The clergy should be the image of God - the Father for the believers ${ }^{19}$. In order to manage to accomplish so demanding vocation, priests need the support from the bishops, who are to be fathers for them, like the Heavenly Father ${ }^{20}$.

\section{Help with undertaking the apostolate}

Francis has repeatedly pointed out that the apostolate is an integral part of the Christian vocation. According to him, the Christian is a man of faith and hope and brings them to others. They are a source of internal dynamism, inducing young people to come out to the other and to share with them the Good News of salvation ${ }^{21}$.

During World Youth Day in Krakow Francis drew attention to two conditions from many existing the fulfillment of which is required to take the Christian apostolate. The first one is memory. In term of memory the Pope understands awareness of the identity and origin, and maintaining them. It is about family and Christian background, as well as an individual way to God. The Pope considers them as a legacy that is the foundation and starting point for activities. ,The young man without memory cannot be hope for the future"22. The task of young people is a concern for the preservation of memory and identity. Older people, especially the ancestors may help with this task. It is also

$18 \quad$ Ibidem, Speech Courageous people (Kraków - the seat of the archbishops 28.07.2016), OsRomPol 47:2016 no. 7-8, p. 17-18.

19 Ibidem, Homily We write down cards of the Gospel of love by our life, p. 23-24.

20 Ibidem, The preaching during the meeting with polish bishops. Gospel of Intimacy, p. 7.

21 H. Tomasik, ,Idźciebezobawy, abystużyç”. Ojciec święty Franciszek do młodzieży, [in:] Duszpasterstwo w świetle nauczania papieża Franciszka, D. Lipiec ed., Lublin 2015, p. 196-198.

22 Ibidem, Speech Two conditions-memory and courage (Kraków - Tauron Arena 31.07.2016), OsRomPol 47:2016, no. 7-8, p. 31. 
necessary the support of the priests responsible for the maintenance and transmission of the Christian tradition ${ }^{23}$. Such assistance is also needed for parents and grandparents who are the communicators of family traditions. Today they have difficulty in the implementation of their mission, because young people do not always want to listen to them and learn about the tradition, which they retain.

According to Francis, the second condition for the apostolate is courage. The Pope sees it as a reality characterized by the present. As far as memory is associated with the past and hope with the future, the courage is associated with the current time, which is to be filled with activity of young people. Courage is a feature characterizing their commitment. It is necessary to take up the challenge of involvement in the transformation of the world, and then to the consistent implementation of the apostolate ${ }^{24}$.

Courage is necessary to transcend their own limitations. As Francis taught, fear arising from the consciousness of having committed sins and various human limitations can be paralysing and discouraging to make any efforts. Instead, it tends to seek peace and stability, even at the expense of giving up ideals ${ }^{25}$. Fear can also take the form of shame in coming out to others. This may be a fear of evaluation, rejection and even aggression ${ }^{26}$. The antidote to fear is to extract the enthusiasm from oneself. This, in turn, is born inside a young man, when he binds himself and his life with Christ. Christ is the source of enthusiasm and courage needed to go to the other and take the apostolate in the world.

Young people need help to overcome fear and anxiety, and in the wake of courage and enthusiasm. They are not always able to take full advantage of the grace that God gives. They often lack the experience of faith and the ability to open up to God. Such support of young people is the task of the Church. It results from the closeness that should characterize the relationship of the young people and priests. The clergy, having the knowledge, skills and experience have the opportunity to give effective help in meeting the challenges of the apostles. Their involvement is also required in the implementation of the apostolate among young people.

$23 \quad$ Cf. D. Lipiec, Teologiczne podstawy duszpasterstwa młodzieży, „Warszawskie Studia Pastoralne" 9:2014, no. 2, p. 26-27.

24 Ibidem.

25 Francis, Speech Nothing justifies the shed of brotherly blood, p. 26-27.

26 Ibidem, Homily Dreamers about a new humanity (Brzegi 31.07.2016), OsRomPol 47:2016, no. 7-8. p. 29. 


\section{Conclusion}

The analysis of the teaching of Pope Francis during the XXXI World Youth Day can be concluded that the youth ministry should be characterized primarily by closeness of priests and young people. This proximity is more of existential than organizational nature. It is characterized by directness of the relationship. The task of priests is to accompany and support young people in their efforts to meet God and bond with Him, the discovery of their own identity and to take and implement the Christian apostolate.

Characteristic of Francis teaching emphasizing the emotional aspect of the Christian faith is also present in the message to the young people. Overcoming fear, shame and awaking of enthusiasm and courage are inseparable elements of young people involved in the Church and in the world. Assistance in sustaining these attitudes is the pastoral task for the clergy, who take care of young people and their families.

\section{IMPLIKACJE NAUCZANIA PAPIEŻA FRANCISZKA PODCZAS ŚWIATOWYCH DNI MŁODZIEŻY W KRAKOWIE DLA DUSZPASTERSTWA MŁODZIEŻY}

W artykule zostało poruszone zagadnienie implikacji nauczania papieskiego podczas Światowych Dni Młodzieży w Krakowie w 2016 roku dla duszpasterstwa młodzieży, a zwłaszcza dla duszpasterstwa młodzieży w Polsce. Na początku przedstawiono kondycję współczesnej młodzieży w ujęciu papieża Franciszka. Następnie, na podstawie analizy nauczania papieskiego wskazano zasadnicze cele pastoralnego towarzyszenia młodym ludziom. Są nimi: pomoc w spotkaniu Boga, pomoc w odkryciu własnego powołania oraz pomoc w podjęciu apostolatu, właściwego wszystkim ochrzczonym. W ramach tych celów zostały wskazane konkretne, szczegółowe zadania dla duchownych pracujących z młodymi ludźmi oraz ich świeckich pomocników.

Słowa kluczowe: Franciszek, Światowe Dni Młodzieży, duszpasterstwo młodzieży.

\section{Bibliography:}

1. Długosz A., Duszpasterstwo młodzieżowe wobec nowych wyzwań, [in:] Gtosić Ewangelię nadziei. Program duszpasterski na rok 2004/2005.

2. Długosz A., Młodzieży duszpasterstwo, [in:] Leksykon teologii pastoralnej, R. Kamiński, W. Przygoda, M. Fiałkowski eds., Lublin 2006. 
3. Francis, Homily Dreamers about a new humanity (Brzegi 31.07.2016), OsRomPol 47:2016 no. 7-8, p. 29.

4. Francis, Homily We write down cards of the Gospel of love by our life (Kraków - Sanktuarium Jana Pawła II 30.07.2016), OsRomPol 47:2016 no. 7-8, p. 24.

5. Francis, Speech Courageous people (Kraków - the seat of the archbishops 28.07.2016). OsRomPol 47:2016 no. 7-8, p. 17-18.

6. Francis, Speech Nothing justifies the shed of brotherly blood (Brzegi 30.07.2016), OsRomPol 47:2016 no. 7-8, p. 25.

7. Francis, Speech Poland wants to be a forever young face of mercy (Kraków - Błonia 28.07.2016), OsRomPol 47:2016 no. 7-8, p. 15.

8. Francis, Speech Two conditions - memory and courage (Kraków - Tauron Arena 31.07.2016), OsRomPol 47:2016 no. 7-8, p. 31.

9. Francis, Speech Where is God? (Kraków - Błonia 29.07.2016), OsRomPol 47:2016 no. $7-8$, p. $20-21$.

10. Francis, The preaching during the meeting with polish bishops. Gospel of Intimacy (Kraków-Wawel 27.07.2016), OsRomPol 47:2016 no. 7-8, p. 7.

11. Lipiec D., Teologiczne podstawy duszpasterstwa młodzieży, „Warszawskie Studia Pastoralne" 9:2014 no. 2, p. 26-27.

12. Święs K., Obraz wspótczesnej młodzieży w Polsce, „Warszawskie Studia Pastoralne" 9:2014, p. 52-54.

13. Tomasik H., „Idźcie bez obawy, aby stużyć”. Ojciec święty Franciszek do młodzieży, [in:] Duszpasterstwo w świetle nauczania papieża Franciszka, D. Lipiec ed., Lublin 2015, p. 196-198.

14. Tomasik H., Wychowanie mtodych do wiary [Education of the young to faith], [in:] Gtosić Ewangelię nadziei. Program duszpasterski na rok 2004/2005, P. Kurzela, A. Liskowacka eds., Katowice 2004, p. 106-115. 